TAPROBANICA, ISSN 1800-427X. August, 2014. Vol. 06, No. 02: pp. 135-136, pl. 14.

(C) Research Center for Climate Change, University of Indonesia, Depok, Indonesia

\& Taprobanica Private Limited, Homagama, Sri Lanka

http://www.sljol.info/index.php/tapro

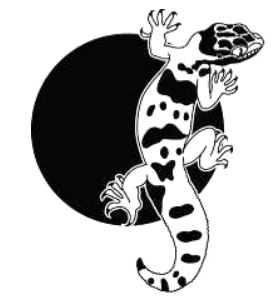

\section{Canscora stricta Sedgw. (Gentianaceae): an endemic species of Western Ghats}

The genus Canscora Lam, known presently from Africa, Australia and tropical Asia, is represented in India by 13 species of which ten are found in Kerala (Sedgwick, 1921; Thiv, 2003; Sasidharan, 2004: 296-297; Nayar et al., 2006: 336-337; Bhat \& Viswanatha, 2009; Diwakar \& Singh, 2009, 2010; Singh \& Diwakar, 2011; Prasad \& Ravi, 2012).

During our taxonomic studies of Gentianaceae in Kerala, India, the authors collected a species of Canscora from the lateritic region of northern Kerala which, on critical examination and perusal of relevant literature, proved to be Canscora stricta Sedgw., a species hitherto known only from Karnataka State of central Western Ghats. It was described by Sedgwick in 1921 based on the collections of Sedgwick \& Bell gathering in 1917 from North Canara (Karnataka) on Castle Rock at an altitude of $1600 \mathrm{~m}$ (Type: BLAT 3393). During the revisionary work of Canscora, Thiv (2003) treated $C$. stricta as doubtful and excluded the species in his treatment due to poor representation of available specimens in herbaria. However, the species was recollected in and around the type locality after a lapse of 92 years which not only confirmed its existence in the wild but also justified the treatment of Sedgwick (l.c.) for erecting a valid species (Bhat \& Viswanatha, 2009; Diwakar \& Singh, 2010). The present collection from Mangattuparamba, Kannur District, Kerala, part of southern Western Ghats, forms a new report and an addition to the flora of Kerala. A detailed description, along with photographs, is provided to facilitate its easy identification.

Canscora stricta Sedgw., J. Ind. Bot. 2: 126, fig. 1921.

Herbs, erect, rigid, 9-20 cm tall. Stems quadrangular; branches obliquely erect.
Leaves cauline, sessile, lanceolate, 3-15 × 1-3 $\mathrm{mm}$, glabrous, sharply acute to acuminate apically; mid vein prominent, lateral veins inconspicuous; lower leaves ovate, found only at early age, deciduous. Flowers subsessile, solitary or in sessile cymes of 3 flowers, terminal or in upper leaf axils; bracts linearsubulate, up to $5 \mathrm{~mm}$ long. Calyx 5-7 $\times 1-1.5$ $\mathrm{mm}$, tubular, 4-lobed; tube 3-6 $\mathrm{mm}$ long, striate, not winged; lobes ca. $2 \mathrm{~mm}$ long, erect, linear. Corolla rose, ca. $11 \mathrm{~mm}$ long; tube ca. $6 \mathrm{~mm}$ long; lobes 4, ovate oblong, subequal, imbricate. Stamens 4, subequal; filaments of upper stamen slightly decurved apically; anthers ca. $0.2 \mathrm{~mm}$ long, versatile. Ovary oblong; style ca. $3.5 \mathrm{~mm}$ long; stigma 2-lobed with the lobes oblong and ca. $2 \mathrm{~mm}$ long. Capsules cylindrical, 3-5 $\times 1.5-2 \mathrm{~mm}$, enclosed within the persistent calyx. Seeds irregular, black when mature. (Fig. 1)

\section{Flowering-Fruiting: September-January}

Distribution: Western Ghats: Karnataka and Kerala. Endemic.

Habitat and Ecology: Canscora stricta grows on lateritic soil during monsoon and associated with Dimeria bialata C. Fischer, D. hohenackeri Hoschst. ex Miq., Lepidagathis keralensis P.V. Madhusoodanan \& N.P. Singh, Polycarpaea corymbosa (L.) Lam., Rhynchospora wightiana (Nees) Steud., Themeda triandra Forssk., etc.

Specimens examined: India, Karnataka, Dakshina kannada Distr., Kaikamba, 26 Sep 2004, K. G. Bhat 11356 (MH); Kerala, Kannur Distr., Mangattuparamba, \pm 80 m, 8 Oct 2012, M. P. Geethakumary \& A. G. Pandurangan 74445 (TBGT).

The Plant List database (www.theplantlist.org) assigns the species to synonymy under Canscora diffusa (Vahl) R. Br. ex Roem. \& 
Schult. However, based on our evaluation, it is a valid species characterised by an erect habit, lanceolate leaf blades, and a solitary or cymose inflorescence in the leaf axils, whereas $C$. diffusa is characterised by a diffused habit, ovate or elliptic leaf blades, and a much branched inflorescence. Canscora stricta is confined to central and southern Western Ghats whereas $C$. diffusa is widely distributed in India, Sri Lanka, tropical Africa, Asia and Australia.

\section{Acknowledgement}

The authors are grateful to Dr. P. G. Latha, Director, Jawaharlal Nehru Tropical Botanic Garden and Research Institute for facilities provided. They are also acknowledging the support and guidance received from Manonmaniam Sundaranar University, Tirunelveli, Tamil Nadu.

\section{Literature cited}

Bhat, K. G. and M. N. Viswanatha, 2009. Two little known plants from Peninsular India. Indian Journal of Forestry, 32: 175-178.

Diwakar, P. G. and R. Kr. Singh, 2009. Canscora sanjappae (Gentianaceae). A new species from Mookambika Wildlife Sanctuary, Karnataka, India. Indian Journal of Forestry, 32: 337-342.

Diwakar, P. G. and R. Kr. Singh, 2010. Rediscovery of Canscora stricta Sedgw. (Gentianaceae) - A little known, strict endemic and threatened taxon from Mookambika Wildlife Sanctuary, Karnataka. Indian Journal of Forestry, 33: 97-98.

Nayar, T. S., A. Rasiya Beegam, N. Mohanan, and G. Rajkumar, 2006. Flowering Plants of Kerala - a Handbook. Tropical Botanic Garden and Research Institute, Thiruvananthapuram: 1062.

Prasad, K. S. and K. Raveendran, 2012. Canscora bhatiana (Gentianaceae), a new species from Kerala, India. International Journal of Plant, Animal and Environmental Sciences, 2: 197-201.

Sasidharan, N., 2004. Biodiversity Documentation of Flora of Kerala - Part 6. Kerala Forest Research Institute, Peechi, Thrissur: 726.

Sedgwick, L. J., 1921. New Bombay species. Journal of Indian Botany, 2: 123-131.
Singh, R. Kr. and P. G. Diwakar, 2011. Canscora devendrae (Gentianaceae) - A new species from Western Ghats, India. Indian Journal of Forestry, 34: 249-252.

Thiv, M., 2003. A taxonomic revision of Canscora, Cracosna, Duplipetala, Hoppea, Microrphium, Phyllocyclus and Schinziella (Gentianaceae-Canscorinae). Blumea, 48: 1-46.

Submitted: 19 Dec. 2013, Accepted: 5 Feb. 2014 Sectional Editor: James L. Reveal

M. P. Geethakumary ${ }^{1}$, A. G. Pandurangan ${ }^{1 *}, \&$ P. Ravichandran ${ }^{2}$

${ }^{1}$ Jawaharlal Nehru Tropical Botanic Garden \& Research Institute, Palode, Thiruvananthapuram 695562, Kerala, India.

${ }^{2}$ Sri Paramakalyani Centre for Environmental Sciences, M. S. University, Alwarkurichi 627412, Tamil Nadu, India. *agpandurangan@gmail.com 


\section{PLATE 14}

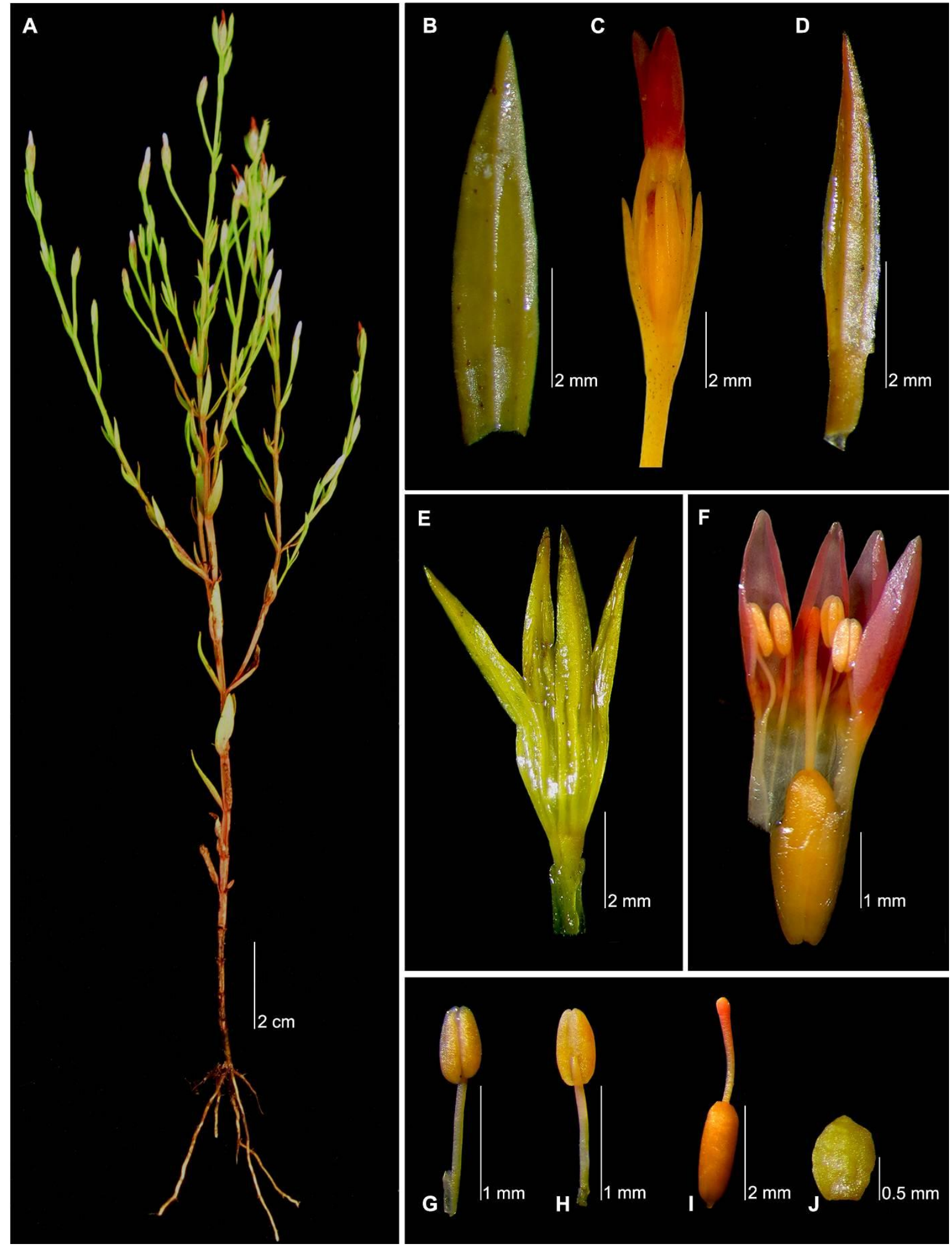

Figure 1: Canscora stricta Sedgw. A. Habit; B. Leaf; C. Flower; D. Bract; E. Calyx; F. Corolla split open with stamens and carpel; G. Stamen dorsal view; H. Stamen ventral view; I. Gynoecium; J. Seed. 